\title{
Maria Hełdak*
}

Agnieszka Stacherzak*

Monika Płuciennik***

Uniwersytet Przyrodniczy we Wrocławiu

\section{ANALIZA ZASAD WYCENY NIERUCHOMOŚCI PRZEZNACZONYCH NA CELE DRÓG PUBLICZNYCH}

\section{Streszczenie}

Artykuł podejmuje temat wyceny nieruchomości przeznaczonych na cele komunikacji publicznej, pozyskiwanych w trybie ustawy o szczególnych zasadach przygotowania i realizacji inwestycji w zakresie dróg publicznych. Wyceny nieruchomości dokonuje się w związku z ustalaniem wysokości odszkodowania za tereny przejęte pod drogi publiczne. Dla realizacji celu opracowania dokonano analizy uwarunkowań prawnych towarzyszących ustalaniu wartości odszkodowania za drogi w tym szczególnym przypadku oraz wskazano najczęściej stosowane metody wyceny w toku pozyskiwania gruntów pod drogi publiczne. Podstawę ustalenia wysokości odszkodowania stanowi w Polsce zazwyczaj wartość rynkowa nieruchomości, ale dla części składowych jest to zwykle wartość odtworzeniowa nieruchomości. Badania ukazały najczęściej wykorzystywane podejścia stosowane w celu ustalenia wysokości odszkodowania za drogi publiczne.

Słowa kluczowe: wycena nieruchomości, drogi publiczne, odszkodowanie

* Adres e-mail: maria.heldak@upwr.edu.pl.

** Adres e-mail: agnieszka.stacherzak@upwr.edu.pl.

*** Adres e-mail: monika.pluciennik@upwr.edu.pl. 


\section{Wstęp}

Zgodnie z rozporządzenie Ministra Rozwoju Regionalnego i Budownictwa z 29 marca 2001 roku w sprawie ewidencji gruntów i budynków (t.j. Dz.U. 2015, poz. 542, z późn. zm.) przez tereny komunikacyjne rozumie się w szczególności:

a) drogi - oznaczone symbolem dr;

b) tereny kolejowe - oznaczone symbolem Tk;

c) inne tereny komunikacyjne - oznaczone symbolem Ti;

d) grunty przeznaczone pod budowę dróg publicznych lub linii kolejowych oznaczone symbolem Tp.

Do użytku gruntowego o nazwie drogi zalicza się grunty, które są pasami drogowymi dróg publicznych oraz dróg wewnętrznych w rozumieniu przepisów ustawy z 21 marca 1985 roku o drogach publicznych (t.j. Dz.U. 2015, poz. 460, z późn. zm.).

Do gruntów przeznaczonych pod budowę dróg publicznych lub linii kolejowych zalicza się grunty, które są własnością Skarbu Państwa lub jednostek samorządu terytorialnego (JST) i zostały wydzielone pod drogi publiczne lub linie kolejowe na podstawie różnych decyzji, ale na których budowa dróg publicznych lub linii kolejowych nie została zakończona.

We współczesnym świecie znaczenie komunikacji jest coraz większe. Powoduje to rozbudowę i modernizację istniejącej sieci komunikacyjnej. W Polsce duży wpływ na rozwój komunikacji miało wejście do Unii Europejskiej oraz organizacja mistrzostw Europy w piłce nożnej. Od momentu wejścia Polski w struktury Unii Europejskiej powstała możliwość skorzystania z unijnych dopłat i funduszy. Wykorzystanie środków z budżetu Unii na rozwój infrastruktury spowodowało, że polski rząd musiał podjąć działania w kwestii uregulowania przepisów w zakresie przygotowania i realizacji inwestycji, w tym głównie budowy sieci dróg. Działania te miały na celu przyśpieszenie całego procesu realizacji dróg publicznych.

Aby osiągnąć te cele i zrealizować zaplanowane inwestycje, 10 kwietnia 2003 roku uchwalona została ustawa o szczególnych zasadach przygotowania i realizacji inwestycji w zakresie dróg publicznych (t.j. Dz.U. 2013, poz. 687, z późn. zm.), która regulowała nabywanie nieruchomości położonych w liniach rozgraniczających teren inwestycji drogowej. W kolejnych latach ustawę nowelizowano w celu ułatwienia procedury nabywania gruntów i przyśpieszenia procesu inwestycyjnego.

Celem opracowania jest analiza zasad wyceny nieruchomości przeznaczonych na cele komunikacji publicznej, pozyskiwanych w trybie tak zwanej specustawy (ustawy o szczególnych zasadach przygotowania i realizacji inwestycji w zakresie 
dróg publicznych). Wyceny nieruchomości dokonuje się w związku z ustalaniem wysokości odszkodowania za tereny przejęte pod drogi publiczne. Dla realizacji celu artykułu dokonano analizy uwarunkowań prawnych towarzyszących ustalaniu wartości odszkodowania za drogi w tym szczególnym przypadku oraz wskazano najczęściej stosowane podejścia w toku pozyskiwania gruntów pod drogi publiczne.

\section{Szczególne zasady przygotowania i realizacji dróg publicznych w Polsce}

Ustawa o szczególnych zasadach przygotowania i realizacji inwestycji w zakresie dróg publicznych zawiera szczególne, odmienne w stosunku do dotychczasowych unormowania prawne. Dotyczą one ustalania lokalizacji dróg, a także podziałów nieruchomości oraz trybu nabywania gruntów pod budowę dróg. Zwykło się ją nazywać specustawą (Wolanin, 2010).

Istotą podjęcia ustawy z 10 kwietnia 2003 roku o szczególnych zasadach przygotowania i realizacji inwestycji w zakresie dróg publicznych (na początku tylko dróg krajowych) (Dz.U. 2013, poz. 687), jaką wcześniej już nazwano „specustawą drogową", była chęć usprawnienia procesu związanego z budową dróg. Poprzez tę ustawę wprowadzono trzyetapowy tryb, zgodnie z którym przygotowywano inwestycję. Pierwszym krokiem było uzyskanie decyzji o ustaleniu lokalizacji drogi, drugim - decyzji o wywłaszczeniu nieruchomości i ostatnim - pozwolenia na budowę. W praktyce okazało się, że proces ten był długotrwały, a ustawa nie przyniosła oczekiwanych skutków.

Wprowadzenie decyzji administracyjnej zezwalającej na realizację inwestycji drogowej umożliwiło JST znaczne przyśpieszenie realizacji inwestycji drogowych (Źróbek, Walacie, 2008; Trembecka, Kwartnik-Pruc, 2009). Nadal jednak realizacja dróg gminnych w głównej mierze odbywa się na podstawie planów miejscowych (Hełdak, Stacherzak, Kazak, 2012; Trembecka, Kwartnik-Pruc, 2009).

Skutkiem powyższego 18 października 2006 roku przyjęto ustawę o zmianie wspomnianej ustawy oraz zmianie niektórych innych ustaw (Dz.U. nr 220, poz. 1601, z późn. zm.). Weszła ona w życie 16 grudnia 2006 roku. Zawiera ona następujące ważne zmiany:

a) rozszerzenie zakresu przedmiotowego na drogi publiczne wszystkich kategorii;

b) wprowadzenie zapisu w art. 12 ust. 4, zgodnie z którym Skarb Państwa z dniem ostateczności decyzji o ustaleniu lokalizacji drogi staje się wła- 
ścicielem nieruchomości, jakie przeznaczono pod pasy drogowe (dotyczy decyzji o lokalizacji drogi krajowej); analogicznie JST stają się właścicielem nieruchomości, jakie przeznaczono pod drogi kategorii niższej (Gdesz, Trembecka, 2011); decyzja ta określała linie rozgraniczające oraz zatwierdzała podział nieruchomości (Źróbek, Walacik, 2008).

Kolejna ważna zmiana „specustawy” weszła w życie 10 września 2008 roku. Wprowadza ona nowy typ decyzji - mowa o decyzji o zezwoleniu na realizację inwestycji drogowej. Stanowi ona rodzaj skonsolidowanego orzeczenia administracyjnego wywołującego wiele skutków, do których należą przede wszystkim:

a) ustalenie lokalizacji inwestycji drogowej;

b) zatwierdzenie podziałów nieruchomości;

c) wywłaszczenie praw do nieruchomości, które znajdują się w granicach inwestycji;

d) zatwierdzenie projektu budowlanego, a także udzielenie pozwolenia na budowę;

e) ograniczenie korzystania z sąsiednich nieruchomości w celu przebudowy infrastruktury technicznej i dróg innej kategorii.

W związku z powyższym wymienione odrębne procedury administracyjne zastąpione zostały jedną procedurą, którą kończy jedna decyzja administracyjna.

Procedura związana z ustawą o szczególnych zasadach przygotowania i realizacji inwestycji w zakresie dróg publicznych dotyczy nieruchomości, które docelowo mają uzyskać status drogi publicznej (Trembecka, 2011). Ma ona zastosowanie zarówno w przypadku nowych inwestycji, jak i tych, w których dochodzi do zmiany granicy pasa drogowego (w tym mostów, tuneli, przepustów i konstrukcji oporowych oraz zjazdów) (Gdesz, Trembecka, 2011).

Ostateczna decyzja pozbawia władającego nieruchomością prawa własności lub innego prawa, które posiada do nieruchomości. Zgodnie z przepisami ustawy nieruchomości lub ich części stają się z mocy prawa:

1) własnością Skarbu Państwa w odniesieniu do dróg krajowych;

2) własnością odpowiednich JST w odniesieniu do dróg wojewódzkich, powiatowych i gminnych

z dniem, w którym decyzja o zezwoleniu na realizację inwestycji drogowej stała się ostateczna. Nieruchomości nabywane są na rzecz podmiotów publicznoprawnych z mocy prawa i proces tego nabycia posiada charakter wywłaszczenia. 


\section{Ustalenie wysokości odszkodowania za grunty przeznaczone pod drogi publiczne}

\subsection{Zasady ogólne}

Za nieruchomości zajęte lub przeznaczone pod drogi publiczne zgodnie z przepisami prawa należy się słuszne odszkodowanie. Zasady ustalania wysokości odszkodowania za grunty przeznaczone pod drogi publiczne regulują takie przepisy prawa, jak:

a) ustawa z 21 sierpnia 1997 roku o gospodarce nieruchomościami;

b) ustawa z 10 kwietnia 2003 roku o szczególnych zasadach przygotowania i realizacji inwestycji w zakresie dróg publicznych;

c) rozporządzenie Rady Ministrów z 21 września 2004 roku w sprawie wyceny nieruchomości i sporządzania operatu szacunkowego.

Odszkodowanie za przejęte nieruchomości powinno realizować konstytucyjny warunek słusznego odszkodowania. Mimo przepisów prawa regulujących zasady ustalania wysokości odszkodowania procedura ta stwarza problemy zarówno organom administracji publicznej, jak i rzeczoznawcom majątkowym. W wielu przypadkach osoby, którym ma być wypłacone odszkodowanie za utracone prawa do nieruchomości, czują się potraktowani niesprawiedliwie.

Problematyka odszkodowań istnieje na dwóch płaszczyznach. Jedna z nich to kwestie związane z przeprowadzaniem postępowania odszkodowawczego, druga zaś dotyczy metodologicznych zasad wyceny w celu określenia wartości praw do nieruchomości zajętych lub przeznaczonych pod drogi publiczne (Śliwiński, 2011).

\subsection{Zasady wyceny nieruchomości przeznaczonych na cele komunikacji publicznej}

Zasady wyceny nieruchomości przeznaczonych na cele komunikacji publicznej zapisane zostały w ustawie z 21 sierpnia 1997 roku o gospodarce nieruchomościami oraz w rozporządzeniu w sprawie wyceny nieruchomości i sporządzania operatu szacunkowego.

Szczegółowe zasady ustalania odszkodowania za wywłaszczone nieruchomości opisane są w rozdz. 5 art. 130 ustawy o gospodarce nieruchomościami. Ustalenie wysokości odszkodowania następuje po uzyskaniu opinii rzeczoznawcy majątkowego. 
W myśl art. 134 przywołanej ustawy wysokość odszkodowania ustalana jest na podstawie wartości rynkowej nieruchomości, przy określaniu wartości rynkowej nieruchomości bierze się pod uwagę w szczególności:

- rodzaj nieruchomości,

- położenie,

- sposób użytkowania,

- przeznaczenie,

- stan nieruchomości,

- aktualnie kształtujące się ceny.

Jeżeli przeznaczenie nieruchomości zgodne z celem wywłaszczenia nie powoduje zwiększenia jej , to wartość rynkową nieruchomości określa się według aktualnego sposobu użytkowania. W przypadku, gdy przeznaczenie nieruchomości powoduje zwiększenie jej wartości, wartość rynkową nieruchomości określa się według alternatywnego sposobu użytkowania (tu według przeznaczania na cele komunikacji drogowej).

Wartość rynkową nieruchomości można określić przy zastosowaniu podejścia porównawczego lub dochodowego. Jeżeli istnieją uwarunkowania niepozwalające na zastosowanie tych podejść, wartość rynkową określa się w podejściu mieszanym.

Wyboru właściwego podejścia, metody i techniki wyceny nieruchomości dokonuje rzeczoznawca majątkowy, biorąc pod uwagę:

- cel wyceny,

- rodzaj nieruchomości,

- położenie nieruchomości,

- przeznaczenie w planie miejscowym,

- stan nieruchomości,

- dane o cenach, dochodach,

- cechy podobnych nieruchomości.

Szczególne zasady określania wartości nieruchomości przeznaczonych pod drogi publiczne zawarte są w rozporządzeniu Rady Ministrów z 21 września 2004 roku w sprawie wyceny nieruchomości i sporządzania operatu szacunkowego. Istotne zmiany w rozporządzeniu zostały wprowadzone 26 sierpnia 2011 roku.

Pierwotnie, zgodnie z zapisami $\S 36$ rozporządzenia, według stanu prawnego przed 26 sierpnia 2011 roku, przy określaniu wartości rynkowej gruntów przeznaczonych na cele komunikacji publicznej należało stosować podejście porównawcze, przyjmując do porównania ceny transakcyjne sprzedaży nieruchomości przeznaczonych pod drogi. Jeżeli na rynku brak było takich transakcji, wartość działki gruntu 
określało się jako iloczyn wartości $1 \mathrm{~m}^{2}$ gruntów, z których wydzielono działki, i ich powierzchni. W przypadku, gdy przeznaczenie gruntów powodowało, że wartość tych gruntów była niższa niż wartość gruntów przeznaczonych pod drogi, wówczas określoną wartość powiększało się o $50 \%$.

Przepisy $§ 36$ określały porządek wyboru transakcji do porównania. W pierwszej kolejności należało wziąć po uwagę ceny uzyskane przy sprzedaży gruntów przeznaczonych lub zajętych pod drogi publiczne. Dopiero w sytuacji, gdy na analizowanym rynku nie występowały tego rodzaju transakcje, można było wykorzystać ceny gruntów o przeznaczeniu przeważającym wśród gruntów przyległych (Trembecka, 2011a). W praktyce przestrzeganie tej zasady było utrudnione, gdyż systematycznie malała liczba transakcji nieruchomości drogowych.

W styczniu 2010 roku Rzecznik Praw Obywatelskich skierował wniosek do Trybunału Konstytucyjnego, w którym stwierdzał niezgodność zapisów § 36 ust. 1 z Konstytucją Rzeczypospolitej Polskiej (Trembecka, 2011b).

Zapisy § 36 zostały zmienione 26 sierpnia 2011 roku. Obecnie ,wartość rynkową nieruchomości dla potrzeb ustalenia odszkodowania za nieruchomości wywłaszczone lub przejęte $\mathrm{z}$ mocy prawa na podstawie przepisów ustawy z dnia 10 kwietnia 2003 r. o szczególnych zasadach przygotowania i realizacji inwestycji w zakresie dróg publicznych określa się, przyjmując stan nieruchomości z dnia wydania decyzji, ceny nieruchomości z dnia ustalenia odszkodowania, a przeznaczenie nieruchomości zgodnie z art. 154 ustawy bez uwzględnienia ustaleń decyzji. Nie uwzględnia się nakładów poniesionych na nieruchomości po dniu wydania decyzji” (Trembecka, 2011.

Główna różnica w odniesieniu do poprzednich zapisów polega na przyjęciu do wyceny dotychczasowego przeznaczenia nieruchomości. Przeznaczenie nieruchomości można określić na podstawie:

- miejscowego planu zagospodarowania przestrzennego,

- studium uwarunkowań i kierunków zagospodarowania przestrzennego gminy,

- decyzji o warunkach zabudowy i zagospodarowania terenu,

- faktycznego sposób użytkowania nieruchomości.

Zgodnie z zapisami rozporządzenia wycena nieruchomości przeznaczonych pod drogi będzie dokonywana na podstawie cen uzyskanych na rynkach właściwych dla wycenianej nieruchomości ze względu na jej przeznaczenie.

W myśl znowelizowanego $\S 36$ ust. 3 „gdy przeznaczenie nieruchomości, zgodne z celem wywłaszczenia, powoduje zwiększenie jej wartości, wartość rynkową nieruchomości określa się w następujący sposób: 
1) wartość działek gruntu wydzielonych pod nowe drogi publiczne albo pod poszerzenie dróg istniejących stanowi iloczyn wartości $1 \mathrm{~m}^{2}$ gruntów, z których wydzielono te działki gruntu, i ich powierzchni,

2) wartość nieruchomości zajętych pod drogi publiczne stanowi iloczyn wartości $1 \mathrm{~m}^{2}$ gruntów o przeznaczeniu przeważającym wśród gruntów przyległych i ich powierzchni - powiększony, na podstawie badania rynku nieruchomości, nie więcej niż o 50\%”.

Wycena nieruchomości opiera się na zasadach sprzed zmian rozporządzenia z tą różnicą, że powiększenie wartości następuje nie więcej niż o 50\%. Ustalenie wartości stawki procentowej należy do zadań rzeczoznawcy majątkowego. Poprzednia sztywna stawka procentowa (50\%) powodowała rozbieżności w wartościach nieruchomości (Trembecka, 2011).

\subsection{Stosowane metody i techniki wyceny nieruchomości przeznaczonych na cele komunikacji publicznej}

Metody i podejścia stosowane w procesie wyceny są uzależnione od uwarunkowań prawnych, celu wyceny oraz przyjętych rodzajów czynników wpływających na wartość nieruchomości. Wyceny nieruchomości dokonuje się przy zastosowaniu podejść: porównawczego, dochodowego lub kosztowego, albo mieszanego, zawierającego elementy podejść poprzednich. Przy zastosowaniu podejścia porównawczego lub dochodowego określa się wartość rynkową nieruchomości. Jeżeli istniejące uwarunkowania nie pozwalają na zastosowanie podejścia porównawczego lub dochodowego, wartość rynkową nieruchomości określa się w podejściu mieszanym. Przy wykorzystaniu podejścia kosztowego określa się wartość odtworzeniową nieruchomości.

Analiza stosowanych metod wyceny nieruchomości przeznaczonych na cele realizacji inwestycji drogowej została przeprowadzona na podstawie operatów szacunkowych w związku z wydanymi decyzjami o zezwoleniu na realizację inwestycji drogowej w powiecie łaskim w 2011 roku. Szerszy zakres analiz dotyczący stosowanych metod wyceny oraz oszacowanych wartości nieruchomości przedstawiono w pracy magisterskiej autorstwa Kałudy (2013). W toku analiz dotyczących ustalenia odszkodowania za grunty przejęte pod drogi ujawniono, że rzeczoznawcy majątkowi przyjmowali najczęściej przeznaczenie ustalone w studium uwarunkowań i kierunków zagospodarowania przestrzennego gmin. Takie postępowanie jest następstwem 
braku obowiązujących planów miejscowych na trasie przebiegu drogi oraz odwołaniem się w przepisach do uwzględnienia przeznaczenia określonego w studium w razie braku planu miejscowego.

Zaskakującym efektem analizy jest ujawnienie faktu, iż w odniesieniu do części składowych nieruchomości rzeczoznawcy majątkowi określali zazwyczaj wartość odtworzeniową nieruchomości. Określenie wartości odtworzeniowej zamiast wartości rynkowej jest zgodne z przepisami prawa, jednak istnieje obawa (o ile nie wynika z przepisów prawa), że podejście było nadużywanie ze względu na łatwiejszy dostęp do danych dotyczących kosztów wytworzenia części składowych nieruchomości.

Plantacje kultur wieloletnich określano przy zastosowaniu przepisów art. 135 ustawy o gospodarce nieruchomościami odnoszących się do ustalania wysokości odszkodowania nasadzeń w przypadku wywłaszczenia. Przy określaniu wartości plantacji kultur wieloletnich szacowano zatem koszty założenia plantacji i jej pielęgnacji do czasu pierwszych zbiorów oraz wartość utraconych pożytków w okresie od dnia wywłaszczenia do dnia zakończenia pełnego plonowania. Sumę kosztów i wartość utraconych pożytków zmniejszono o sumę rocznych odpisów amortyzacyjnych wynikającą z okresu wykorzystania plantacji od pierwszego roku plonowania do dnia wywłaszczenia.

Pomimo rolniczego charakteru nieruchomości odszkodowania za drogę publiczną oszacowano najczęściej na podstawie cen transakcyjnych nieruchomości drogowych. Trasa przebiegu drogi ekspresowej na tym odcinku biegła w głównej mierze po gruntach użytkowanych rolniczo, których wartość jest niższa od wartości terenów komunikacyjnych. Zastosowano zatem wariant wyceny, w którym cel wywłaszczenia powoduje wzrost wartości nieruchomości. Tam, gdzie przeznaczenie zgodne z celem wywłaszczenia nie spowodowało zwiększenia wartości nieruchomości, wycenę przeprowadzono na podstawie cen transakcyjnych nieruchomości podobnych, które stanowiły najczęściej działki budowlane (tereny mieszkaniowe, usługowe).

\section{Podsumowanie}

Podjęte badania pozwoliły na sformułowanie poniższych wniosków:

1. Zasady wyceny nieruchomości przeznaczonych pod drogi publiczne ulegały wielu zmianom od momenty wejścia w życie ustawy o szczególnych zasadach przygotowania i realizacji dróg publicznych. Główna różnica w od- 
niesieniu do poprzednich zapisów ustawy polega na przyjęciu do wyceny dotychczasowego przeznaczenia nieruchomości (bez uwzględnienia ustaleń decyzji). Zgodnie z zapisami rozporządzenia w sprawie wyceny nieruchomości i sporządzania operatu szacunkowego wycena nieruchomości przeznaczonych pod drogi dokonywana jest obecnie na podstawie cen uzyskanych na rynkach właściwych dla wycenianej nieruchomości ze względu na jej przeznaczenie.

2. Nabywanie nieruchomości komunikacyjnych budzi wiele kontrowersji, a proces nabycia posiada charakter wywłaszczenia. Pozyskiwaniu gruntów na cele budowy dróg publicznych często towarzyszy niechęć właścicieli do zbywania swoich gruntów. Problem ten pogłębia fakt, że odszkodowanie nie uwzględnia takich elementów, jak koszty i opłaty związane z nabyciem nowej nieruchomości (m.in. podatek VAT, koszty sporządzenia umowy i wpisów w księgach wieczystych, koszty obsługi prawnej, koszty pośrednictwa, koszty przeprowadzki). Dotyka to w szczególności tych właścicieli, którzy zmuszeni są opuścić miejsce zamieszkania.

3. Rzeczoznawcy majątkowi określają zazwyczaj wartość rynkową nieruchomości, uwzględniając najczęściej ustalenia studium uwarunkowań i kierunków zagospodarowania przestrzennego gminy, biorąc pod uwagę nadal niewielkie pokrycie obszarów gmin planami miejscowymi. Części składowe nieruchomości biegli określają najczęściej jako wartość odtworzeniową nieruchomości. Związane jest to zapewne z brakiem odpowiedniego materiału porównawczego - zazwyczaj fragment nieruchomości zabudowanej przechodzi na własność (rzadko cała nieruchomość), co utrudnia znalezienie transakcji nieruchomości porównywalnych.

\section{Literatura}

Gdesz, M., Trembecka, A. (2011). Regulowanie stanu prawnego nieruchomości pod drogi. Katowice: Gall.

Hełdak, M., Stacherzak, A., Kazak, J. (2012). Problemy realizacji ustaleń planu miejscowego w zakresie komunikacji na obszarach wiejskich. Infrastruktura i Ekologia Terenów Wiejskich, 2 (III), 79-88.

Kałuda, M. (2013). Analiza stosowanych metod wyceny nieruchomości przeznaczonych na cele komunikacji publicznej. Praca magisterska wykonana na Uniwersytecie Przyrodniczym we Wrocławiu. 
Rozporządzenie Ministra Rozwoju Regionalnego i Budownictwa z 29.03.2001 w sprawie ewidencji gruntów i budynków. Dz.U. nr 38, poz. 454.

Rozporządzenie Rady Ministrów z 21.09.2004 w sprawie wyceny nieruchomości i sporządzania operatu szacunkowego. Dz.U. nr 207, poz. 2109, z późn. zm.

Śliwiński, Ł. (2011). Odszkodowanie za nieruchomości przeznaczone pod drogi publiczne. Studia i Materiaty Towarzystwa Naukowego Nieruchomości, 19 (4), 191-202.

Trembecka, A. (2011a). Jedna decyzja zamiast pięciu. Magazyn Geoinformacyjny Geodeta, $11,39-40$.

Trembecka, A. (2011b). Według wartości rynkowej. Magazyn Geoinformacyjny Geodeta, $12,54$.

Trembecka, A., Kwartnik-Pruc, A. (2009). Geodezyjno-prawne problemy związane z przygotowaniem dokumentacji dla celów inwestycji drogowych na terenie Krakowa. Archiwum Fotogrametrii, Kartografii i Teledetekcji, 19, 437-445.

Ustawa z 21.08.1997 o gospodarce nieruchomościami. t.j. Dz.U. 2015, poz. 782, z późn. zm. Wolanin, M. (2010). Ustawa o szczególnych zasadach przygotowania i realizacji inwestycji w zakresie dróg publicznych. Komentarz. Warszawa: C.H. Beck.

Źróbek, S., Walacik, M. (2008). Problematyka nabywania gruntów pod budowę dróg. Studia i Materiały Towarzystwa Naukowego Nieruchomości, 16 (1), 95.

\title{
AN ANALYSIS OF VALUATION PRINCIPLES OF THE PROPERTIES INTENDED FOR PUBLIC ROADS
}

\begin{abstract}
The paper discusses the valuation principles of the properties intended for public transport acquired pursuant to the Act on special principles of preparing and executing of public road construction investment projects. Property valuation is done due to estimate the amount of compensation for the land sourced to develop public roads. For the purpose of the article an analysis of legal aspects of estimation of compensation value in this particular case was carried out and the most frequently used methods of valuation in land acquisition for public roads were demonstrated. In Poland the basis on which the amount of compensation is established is usually the market value of the property, but for a component of the property it is most often its replacement value. The research has shown most commonly used approaches used for establishing the amount of compensation for land allocated for construction of public roads.
\end{abstract}

\section{Translated by Maria Hetdak, Agnieszka Stacherzak, Monika Płuciennik}

Keywords: property valuation, public roads, compensation JEL Codes: R42, R54 
